TABLE VI-Residues in Human Fat in Various Countries

\begin{tabular}{|c|c|c|c|c|c|c|c|c|c|}
\hline & & & \multirow{2}{*}{ Period } & \multirow{2}{*}{$\begin{array}{l}\text { No. of } \\
\text { Samples }\end{array}$} & \multicolumn{4}{|c|}{ Mean Residues (mg/kg) } & \multirow{2}{*}{ References } \\
\hline & & & & & Total BHC & $\begin{array}{c}\text { Dieldrin } \\
\text { (HEOD) }\end{array}$ & $p p^{\prime}-\mathrm{DDE}$ & $p p^{\prime}-\mathrm{DDT}$ & \\
\hline $\begin{array}{l}\text { U.K. } \\
\text { New Zealand } \\
\text { Denmark } \quad . . \\
\text { Italy... } \quad . . \\
\text { Australia } \quad \ldots \\
\text { Israel } \quad \ldots \\
\text { U.K. } \\
\text { California, U..S. } \\
\text { Florida, U.S. } \\
\text { Hawaii, U.S. } \\
\text { Holland } \quad . . \\
\text { Canada } \\
\text { Arizona, U.S. } \\
\text { Florida, U.S. } \\
\text { Hungary . . } \\
\text { Federal Republic o } \\
\text { U.K. }\end{array}$ & 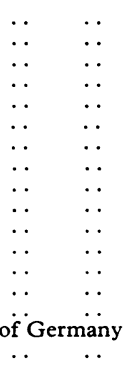 & 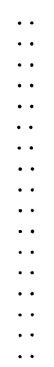 & $\begin{array}{l}1963-4 \\
1963-4 \\
1965 \\
1965 \\
1965-6 \\
1965-6 \\
1965-7 \\
1967 \\
1967 \\
1967-8 \\
1967-8 \\
1967-8 \\
1967-8 \\
1968-9 \\
1969 \\
1970 \\
1969-71\end{array}$ & $\begin{array}{r}65 \\
45 \\
18 \\
9 \\
12 \\
133 \\
248 \\
64 \\
42 \\
11 \\
11 \\
51 \\
70 \\
90 \\
20 \\
201\end{array}$ & $\begin{array}{l}0.42 \\
0.50 \\
= \\
0.68 \\
\overline{0.31} \\
= \\
= \\
= \\
\overline{=} \\
2.3 \\
0.45 \\
0.29\end{array}$ & $\begin{array}{l}0.26 \\
\overline{0.20} \\
\overline{0.67} \\
\overline{0.21} \\
\overline{0.21} \\
0.03 \\
0 \cdot 17 \\
0.12 \\
0.14 \\
= \\
= \\
0 \cdot 16\end{array}$ & $\begin{array}{l}2 \cdot 0 \\
\frac{1}{2 \cdot 5} \\
2 \cdot 86 \\
6 \cdot 3 \\
9 \cdot 9 \\
2 \cdot 0 \\
16 \cdot 1 \\
6 \cdot 69 \\
4 \cdot 64 \\
1 \cdot 70 \\
4 \cdot 16 \\
4 \cdot 58 \\
5 \cdot 5 \\
6 \cdot 74 \\
2 \cdot 2 \\
1 \cdot 8\end{array}$ & $\begin{array}{l}1 \cdot 1 \\
0.60 \\
1.46 \\
2.5 \\
8 \cdot 2 \\
0.78 \\
4 \cdot 8 \\
2.77 \\
1.33 \\
0.32 \\
1.56 \\
1.54 \\
2.3 \\
5.57 \\
1.1 \\
0.52\end{array}$ & $\begin{array}{l}\text { Egan et al. (1965) } \\
\text { Dacre (1969) } \\
\text { Weihe (1966) } \\
\text { Kanitz and Castello (1966) } \\
\text { Wassermann et al. (1968) } \\
\text { Wassermann et al. (1967) } \\
\text { Abbott et al. (1968) } \\
\text { Rappolt and Hale (1968) } \\
\text { Radomski et al. (1968) } \\
\text { Casarett } \text { et al. }(1968) \\
\text { de Vlieger et al.(1968) } \\
\text { Kadis } \text { et al. (1970) } \\
\text { Morgan and Roan (1970) } \\
\text { Davies et al. (1969) } \\
\text { Berend et al. (1970) } \\
\text { Acker and Schulte (1970) } \\
\text { Present paper }\end{array}$ \\
\hline
\end{tabular}

analyses of the results. This report is made by permission of the Government Chemist (Department of Trade and Industry) and the Department of Health and Social Security.

\section{References}

Abbott, D. C., Goulding, R., and Tatton, J. O'G. (1968). British Medical Fournal, 3, 146.

Abbott, D. C., Holmes, D. C., and Tatton, J. O'G. (1969). Fournal of the Science of Food and Agriculture, 20, 245.

Acker, L., and Schulte, E. (1970). Naturwissenschaften, 57, 497.

Berend, E., Kecskemeti, I., and Koppa, G. (1970). Egészségtudomány, 14,

388.
Casarett, L. J., Fryer, G. C., Yauger, W. L., and Klemmer, H. W. (1968). Archives of Environmental Health, 17, 306.

Collins, G. B., Holmes, D. C., and Jackson, F. J. (1972). In preparation.

Dacre, J. C. (1969). Proceedings of the University of Otago Medical School, 47, 74.

Davies, J. E., Edmundson, W. F., Carter, C. H., and Barquet, A. (1969). Lancet, $2,7$.

Department of Education and Science, (1969). Further Review of Certain Persistent Organochlorine Pesticides, London, H.M.S.O.

de Vlieger, M., Robinson, J., Baldwin, M. K., Crabtree, A. N., and van Vlieger, M., Robinson, J., Baldwin, M. K., Crabtree, A. N.,
Dijk, M. C. (1968). Archives of Environmental Health, 17, 759.
Egan, H., Goulding, R., Roburn, J., and Tatton, J. O'G. (1965). British Medical fournal, 2, 66 .

F.A.O./W.H.O. (1970). World Health Organization Technical Report Series, No. 458.

Government Chemist (1963-1971). Reports. London, H.M.S.O.

Kadis, V. W., Breitkreitz, W. E., and Jonasson, O. J. (1970). Canadian Fournal of Public Health, 61, 413.

Kanitz, S., and Castello, G. (1966). Giornale di Igiene e Medicina Preventiva, $7,1$.

Ministry of Agriculture, Fisheries and Food (1964). Review of the Persistent Organochlorine Pesticides. London, H.M.S.O.

Morgan, D. P., and Roan, C. C. (1970). Archives of Environmental Health, 20, 452.

Radomski, J. L., Diechmann, W. B., Clizer, E. E., and Rey, A. (1968). Food and Cosmetics Toxicology, 6, 209.

Rappolt, R. R., and Hale, W. E. (1968). Clinical Toxicology, 1, 57.

Simmons, J. H., and Tatton, J. O'G. (1967). Fournal of Chromatography, 27, 253 .

Thomson, J. F., Walker, A. C., and Mossman, R. F. (1969). fournal of the Association of Official Analytical Chemists, 52, 1251, 1263.

Wassermann, M., Curnow, D. H., Forte, P. N., and Groner, Y. (1968). Industrial Medicine and Surgery, 37, 295.

Wassermann, M., Wassermann, D., Zellermeyer, L., and Gon, M. (1967). Pesticides Monitoring Fournal, i, No. 2, 15.

Weihe, M. (1966). Ugeskrift for Laeger, 128, 881 .

Widmark, G. (1967). Fournal of the Association of Official Analytical Chemists, 50, 1069 .

\title{
Varicose Veins, Deep Vein Thrombosis, and Haemorrhoids: Epidemiology and Suggested Aetiology
}

\author{
DENIS P. BURKITT
}

British Medical fournal, 1972, 2, 556-561

\section{Summary}

Current concepts on the aetiology of varicose veins, deep vein thrombosis, and haemorrhoids have been examined and, in the light of epidemiological evidence, found wanting.

It is suggested that the fundamental cause of these disorders is faecal arrest which is the result of a low-residue diet.

\section{Introduction}

Varicose veins and haemorrhoids are among the most common ailments of economically developed countries. Varicose veins are present in 10-17\% of adults in England (de Takatas and

Medical Research Council, London W.1

DENIS P. BURKITT, M.D., F.R.C.S., F.R.S., Member of External Staff
Quint, 1930; Dodd and Cockett, 1956; Martin et al., 1956; Allen et al., 1962) and in North America (Davis, 1968). The Ministry of Pensions and National Insurance (1962) recorded that just under four million working days were lost in Britain in 1959-60 due to these two conditions.

The incidence of deep venous thrombosis in hospital patients varies with the criteria used in diagnosis. Lambie et al. (1970), using ${ }^{1 \%}$ I-labelled fibrinogen, showed that nearly half of those they termed "high risk" surgical patients in Britain developed some degree of venous thrombosis. Kakkar et al. (1970) estimated its incidence as $20-30 \%$ of all surgical patients and $40-45 \%$ in older patients undergoing major operations. Deep vein thrombosis is, moreover, no less common in severe medical illnesses (Nicolaides et al., 1971). Flanc et al. (1969) found that about $35 \%$ of patients over the age of 40 developed thrombosis in spite of conventional prophylactic measures. Besides being an important cause of postoperative disability, venous thrombosis is the root cause of one of the most dreaded disasters of surgery-pulmonary embolism, which kills about 2,500 people in Britain annually (General Register Office, 1969). Some degree of pulmonary embolism is believed to occur in half of all patients who develop ileofemoral thrombosis (Mavor, 1969). More- 
over, the late sequelae of the post-phlebotic syndrome form one of the commonest and most intractable problems in medicine (Lancet, 1971). Pulmonary embolism has been estimated to be responsible for 5-9\% of hospital deaths (Coon and Coller, 1959; Davis, 1968). More than $95 \%$ of these lethal emboli are believed to originate in the lower limbs.

If the steadily rising incidence in deaths from thrombosis and pulmonary embolism (Morrell et al., 1963) continues at its present rate a tenfold increase will have occurred over a 30-year period by 1973 (Roberts, 1971).

Evidence supporting the hypothesis that varicose veins, deep vein thrombosis, pulmonary embolism, and haemorrhoids have one important aetiological factor in common will be presented. The argument outlined here concerns only the most common type of varicose veins, the so-called "idiopathic," since varicose veins due to pathological obstruction of venous channels are relatively rare and their explanation is obvious.

\section{Geographical Distribution}

It is essential at the outset to stress that the geographical distribution of varicose veins and deep vein thrombosis is almost identical. The distribution of haemorrhoids is similar, but the incidence of this condition rises in any community before that of varicose veins. I have been unable to find evidence of a reverse situation. These three conditions are common in economically developed communities, rare in all developing countries, and almost unknown in tribal communities where the influence of Western countries is slight. Where Western dietary customs have been adopted over recent years-for example, in urban Africa-there is an increasing incidence of these diseases.

In India, Pakistan, and the Middle East the situation is midway between that of Africa and North America.

In Japan all these venous disorders are much less common than in North America but more prevalent than in Africa. They are becoming more common (K. Kushima, personal communication, 1971).

\section{VARICOSE VEINS}

The high incidence of varicose veins in both North America and Europe contrasts with their rarity in Africa and India, particularly in rural communities. D. Webster (personal communication, 1971) specifically looked for varicose veins for over a year in a hospital dealing annually with some 30,000 outpatients serving a tribe in Africa which is still almost unaffected by Western civilization. He found only one case. Over ten years ago I specifically looked for varicose veins when examining more than 4,000 adults during a sleeping sickness inspection in one of the less developed areas of Central Africa and detected only five cases, an incidence of $0 \cdot 12 \%$-that is, about $1 / 1,000$ of the incidence in Great Britain.

In an area somewhat more developed in Malawi R. J. Harvey (personal communication, 1971) found an incidence of about $0.2 \%$ in recruits for work in the South African mines who were aged 18 to 40 . Barker (1964) saw five cases of varicose veins among 14,000 patients admitted to the Charles Johnson Memorial Hospital in Zululand. Replies to a questionnaire distributed to doctors in 114 mission hospitals in 20 countries in subSaharal Africa indicated that $89(78 \%)$ estimated that they saw fewer than five patients with varicose veins annually. Only three doctors, who worked in Rhodesia or South Africa, saw more than 20 cases in hospitals admitting on average about 2,000 patients annually, and their outpatient attendances approached 20,000 .

Inquiries at 33 mission hospitals in India and Pakistan showed that 16 had seen fewer than five patients annually with varicose veins, and only five hospitals had seen more than 20 cases.
Varicose veins are rare in Japan (K. Kushima, personal communication, 1971).

\section{VENOUS THROMBOSIS}

Thomas et al. (1960), comparing the necropsy incidence of thromboembolic phenomena, found that in American Whites and Negroes it was $24 \%$ and $22 \%$ respectively, but only $2 \%$ in Ugandan Africans. In 110 of the 114 mission hospitals in Africa referred to above, doctors estimated that they saw fewer than five cases of overt deep venous thrombosis yearly. More than half of them did not see one a year.

Of the 33 mission hospitals in India and Pakistan mentioned above, 13 did not see one case of clinically recognizable deep vein thrombosis a year, and only five saw over five.

Dodd (1964) reported only three cases of femoral thrombosis among over 11,000 inpatients, which included over 3,000 maternity cases, at the Charles Johnson Memorial Hospital in Zululand. These observations indicate that deep vein thrombosis is detected in about 1 in 5,000 to 1 in 10,000 admissions in upcountry hospitals in Africa. Even if this figure refers only to patients with obvious oedema, the prevalence is low.

Luyombya-Sengero (1968) showed a rise in incidence of thromboembolic episodes found at necropsy in Uganda from $2.4 \%$ in the period $1951-6$ to $6 \%$ in the years $1965-7$. Both these figures are low compared with estimates of venous thrombosis in medical and surgical necropsies in Britain which vary from 44 to $60 \%$ (Kemble, 1971).

There is evidence that in England deep vein thrombosis is less common among immigrants from India and Pakistan than in the indigenous population (G. Sianey, personal communication, 1971). Among 46,500 patients known to have been born in Britain discharged from Birmingham hospitals in 1969 there were 138 recorded cases of venous embolism and thrombosis. No case of thrombosis or embolism was recorded among 1,976 patients known to have been born in India or Pakistan. Although place of birth was recorded in only two-thirds of all admissions, these figures suggest a lower incidence of thrombus in the immigrant population.

\section{PULMONARY EMBOLISM}

Davies (1948) found only one case of fatal pulmonary embolism when reviewing 159 cases of sudden death traced from necropsy records of Africans in Kampala. Doctors from two hospitals in Nigeria and one in Zaire (formerly Belgian Congo), each admitting over 6,000 patients annually, could remember no case of confirmed pulmonary embolism. S. G. Browne (personal communication, 1970) and J. Wilkinson (personal communication, 1970) each remembered only one case in over 20 years' experience in Zaire and Kenya respectively. Only three cases were seen after 10,909 operations on Africans in Johannesburg (Barlow et al., 1953).

Fatal pulmonary embolism is almost unknown at the King Edward Memorial Hospital, Bombay, with over 61,000 admissions annually from the lower income groups (P. K. Sen, personal communication, 1971).

\section{HAEMORRHOIDS}

Haemorrhoids are rare throughout rural Africa and almost unknown in the more primitive communities. Dodd (1964) recorded only one case at the Charles Johnson Memorial Hospital during a three-year period in which over 11,000 patients were admitted and over 100,000 outpatients seen. Trowell (1960) reported that he had seen only two cases of anaemia due to bleeding piles in 30 years in East Africa, and one was a prince on a semi-European diet. Southern Nigerians, who have been 
exposed to Western influences for much longer than people in East or Central Africa, seem to have a significantly higher incidence of haemorrhoids. Throughout India and Iran haemorrhoids are much more prevalent than in Africa, although varicose veins are still rare.

Not only does the rarity of these conditions in rural Africa contrast with the situation in the American Negro, but it is in the urban population that the incidence is now rising. C. G. Bremner (personal communication, 1970) reported an elevenfold increase in haemorrhoidectomies and a sevenfold increase in operations for varicose veins in Baragwanath Hospital, Johannesburg, between 1960 and 1969 .

\section{New Look at Accepted Concepts of Aetiology}

\section{VARICOSE VEINS}

Causes most frequently suggested include: (1) maladjustment to evolutionary changes, (2) heredity, (3) prolonged standing, (4) pregnancy, (5) constrictive clothing, and (6) femoral thrombosis. In the light of the above evidence such explanations demand re-examination.

Maladjustment to Evolutionary Changes.-Man's erect posture has usually been considered the most important causal factor, but only because varicose veins are limited to human beings. One of the best and most popular of British surgical textbooks, Bailey and Love's Short Practice of Surgery (1968) dismissed the aetiology of varicose veins with the single statement that varicose veins are part of the penalty we pay for the adoption of the upright posture. Cleave (1960) and Cleave et al. (1969) showed this reasoning to be untenable in view of geographical distribution.

Heredity.-Many standard works (Martin et al., 1956; Allen et al., 1962) consider a transmissible weakness in the vessel walls or valves to be the most important underlying cause of varicose veins, a conclusion which stems from a tendency for the disease to run in families. The strongest argument against genetic endowment playing a primary part is that varicose veins are now equally common in American Negroes and Whites (Stamler, 1958; Menendez, elucidated by Cleave, 1960), whereas the condition is still rare in the parts of Africa from which these Negroes originated. Varicose veins are, moreover, much more prevalent among New Zealand Maoris than in the less Westernized though ethnically similar Polynesian islanders (I. A. M. Prior, personal communication, 1970). Another factor suggesting that heredity is not of primary aetiological importance in common diseases is that no true congenital deformity occurs in more than $0.5 \%$ of live births (Grundy and Lewis-Faning, 1957). Cleave (1960) deduced that it is therefore most unlikely that any condition over 20 times as common as this can be primarily an inherited defect. He pointed out that this does not discount the existence of familial tendencies to develop varicose veins, provided that a primary causative factor is present, and it is these tendencies that result in a high incidence in some families.

Prolonged Standing.-This may be a contributory factor (Mekky et al., 1969) but it cannot be a primary cause. There is no evidence that Africans or Indians stand for less time than Europeans or North Americans. Many have identical or similar employment yet are free from varicose veins.

Pregnancy. - There are no grounds for incriminating pregnancy as a primary causative factor. Women in countries with a low frequency of varicose veins have on average more pregnancies than those in communities with a high incidence. Moreover, as T. L. Cleave (personal communication, 1971) pointed out, the human race must be adapted to the circumstances of normal pregnancy. Evidence from Africa and India suggests that the varicosities appearing during pregnancy tend to disappear after delivery.

Constrictive Clothing.-This cannot be a major factor for women's dress in the Western world is no more constrictive than that worn by women in many countries where varicose veins are virtually unknown. Moreover, it cannot account for the high incidence in men.

Femoral Thrombosis.-Except in a few individual patients varicose veins cannot be attributed to deep vein thrombosis as the former become common in a community before the latter.

\section{DEEP VEIN THROMBOSIS AND PULMONARY EMBOLISM}

Over 120 years ago Virchow (1856) suggested that the possible causes of deep vein thrombosis could be divided into three main groups: local changes in the vessel wall, venous stasis, and changes in the coagulability of the blood. It has recently been reasserted that the main aetiological factor is an increased tendency of the blood to clot (Doran, 1971). Venous return has been shown to fall to half its normal rate during operation (Doran et al., 1964; Clarke and Cotton, 1968), and even during postoperative bed recumbency (Wright et al., 1951). In keeping with these observations Gibbs (1959) and Sevitt and Gallagher (1959) showed that immobilizing a patient for more than three days induces a serious risk of deep vein thrombosis.

Negus et al. (1969) failed to show any difference in platelet adhesiveness between patients with and without deep vein thrombosis.

The observation that deep vein thrombosis is rare in the upper limbs, even in unconscious or quadriplegic patients with all four limbs equally immobile, suggests that if slowing of venous blood flow contributes to venous thrombosis it must be caused by a factor operating selectively on the veins of the lower limb. For the same reason it seems unlikely that the abnormal fibrinolytic activity in different individuals (Chakrabarti et al., 1968) or between racial groups (Shaper et al., 1966; Shaper, 1970) is a major factor.

In the light of these observations early postoperative ambulation and intensive physiotherapy have been advocated to combat venous stagnation. More recently emphasis has been switched to the possibility of the original clots actually forming in the operating theatre, and some have used intermittent pressures applied to the lower limbs to maintain venous circulation and minimize clot formation (Calnan et al., 1970; Sabri et al., 1971). Others have maintained foot movements with a mechanical device (Roberts, 1971; Roberts et al., 1971) or used electrical stimulation of calf muscles (Browse and Negus, 1970; Doran et al., 1970).

Neither operative conditions nor postoperative immobilization with the accompanying venous stagnation are peculiar to the Western world and can therefore be only precipitating factors in the presence of some fundamental cause. This is not to deny that all the above measures are doubtless of value in lowering the incidence of deep vein thrombosis within a susceptible community.

Modern techniques using phlebography and radioactive fibrinogen indicate that thrombosis occurs with identical frequency in either leg (Browse and Negus, 1970; Kakkar et al., 1970; Kemble, 1971; Sripad et al., 1971), whereas clinically recognizable cases, and in particular ileofemoral thrombosis, have been reported to be two or three times more common in the left leg (Atkins, 1938; Barker, 1941; Negus, 1970). This discrepancy is understandable in view of observations that venous thrombosis can be detected clinically only in $50-90 \%$ of patients. Not only may thrombosis be clinically undetectable but clinical signs may be present in the absence of a thrombus (Kemble, 1971).

The identical incidence of thrombosis in both legs, together with the left-sided preponderance of clinical manifestations, suggests that some primary factor produces an equal effect on the veins of both legs, probably before admission to hospital, and that an additional factor predisposes to extension and clinical expression of thrombus on the left side. 
HAEMORRHOIDS

Haemorrhoids have been attributed to man's erect posture, heredity, absence of valves in the portal system, anatomy of the collecting veins in the lax rectal submucosa, and the liability of these veins to compress as they traverse the muscular wall of the rectum. Suggested subsidiary causes include straining at stool, strenuous work, prolonged standing, poor sphincteric control in the aged, pregnancy, and fibroid and other abdominal tumours. Gabriel (1963) even included horse-riding.

Such attempts to explain the development of these venous disorders were based on experience in Europe and North America. However, we now know that conditions in these continents do not represent the norm since no account is taken of their differing incidence throughout the world. Neither erect posture nor the anatomy of the portal system or of the haemorrhoidal valves is peculiar to Westernized people, neither do they engage in more prolonged standing or have more pregnancies or uterine fibroids than do rural Africans.

Some authors, including Stelzner (1963), consider the haemorrhoidal veins as a cavernous system, but this does not have any effect on the argument.

The factors considered above which have been eliminated as being primary causes of these various venous disorders may, however, be contributory or aggravating factors in the presence of a primary cause.

\section{Link with Diseases Characteristic of Economic Development}

The company kept by any particular disease can be a guide to its aetiology, because conditions occurring together both geographically and in individual patients should be suspected of having a common or related cause (Burkitt, 1969, 1970). Varicose veins, deep vein thrombosis, and pulmonary embolism, together with haemorrhoids, are epidemiologically closely related to a number of diseases characteristic of economic development. These include such non-infective diseases of the bowel as appendicitis, cancer, polyps, and diverticular disease, and also apparently unrelated conditions like obesity, diabetes, atherosclerosis, cholecystitis, hiatus hernia, and femoral hernia. Cleave et al. (1969) included these and other diseases characteristic of Western civilization under an inclusive term, the "saccharine disease," meaning related to sugar (the word "saccharine" being pronounced like the river Rhine). They pointed out that the refining of carbohydrate leads to three main dietary defects: fibre deficiency; overconsumption of the refined product, which is the inevitable result of reducing the bulk so enabling a greater intake; and the removal of protein. They contended that the removal of fibre is the basic cause of constipation, with the diseases consequent on it, and the overconsumption of the refined product the main cause of obesity, diabetes, and atherosclerosis.

It is the first of these causes, the removal of fibre, with resulting constipation, which is believed to contribute to the pathogenesis of varicose veins, deep vein thrombosis, and haemorrhoids. The others are mentioned merely to explain the epidemiological relations which must be accounted for in any adequate hypothesis for the cause of these venous disorders. For example, it would help to explain the association between obesity and deep vein thrombosis in individual patients (Little et al., 1966; Richards, 1966).

\section{Observations to be Explained}

Any adequate hypothesis for the causation of varicose veins, deep vein thrombosis, and haemorrhoids should explain the following observations: (1) similarity in the geographical distribution of these conditions, (2) rarity in all developing countries contrasted with the high incidence in more affluent communi- ties, (3) contrast between the high incidence among American Negroes and the low incidence in Africans, (4) relation between these conditions and certain other diseases characteristic of economic development, (5) almost complete exemption of the upper limb from deep vein thrombosis, (6) higher incidence of varicose veins in women than in men, (7) tendency for thrombi in the left leg to extend further than in the right leg, thus becoming clinically detected in a higher proportion of cases, and (8) incidence of haemorrhoids in a community rising before that of varicose veins.

\section{Dietary Fibre and Intestinal Behaviour and Content}

Before discussing Cleave's hypothesis, with the basic principle of which I am in complete agreement, it is necessary to summarize the effect of diet on intestinal content and behaviour, for I believe that herein lies the fundamental cause of the venous disorders under consideration.

Extensive studies in many countries in Africa and elsewhere, and in people with differing dietary habits in England (Walker, 1961, 1971; Burkitt, 1971; Burkitt et al., 1972) have shown a direct relation between the amount of indigestible fibre eaten and both the intestinal transit time and stool weight, bulk, and consistency. A fibre-deficient diet results in a prolonged transit time which is associated with small, firm, formed stools, while a diet with adequate fibre has the reverse effect. Campbell and Cleave (1968) were the first to record this in tribal Africans.

A group of African villagers on an unrefined diet passed an average of over $400 \mathrm{~g}$ of soft stool a day and evacuated $80 \%$ (20 out of 25) swallowed markers within an average of 35 hours. Senior boys at an English public school and also Royal Navy personnel (J. Milton Thompson, personal communication, 1971) on normal British diet passed on average only $108 \mathrm{~g}$ of stool daily with an average transit time of 77 hours. Senior African schoolboys on a traditional diet supplemented by European type food showed intermediate bowel behaviour, passing an average of $185 \mathrm{~g}$ a day with transit times averaging 47 hours, and vegetarians in England have shown bowel behaviour similar to the boys in the African school (see Chart).

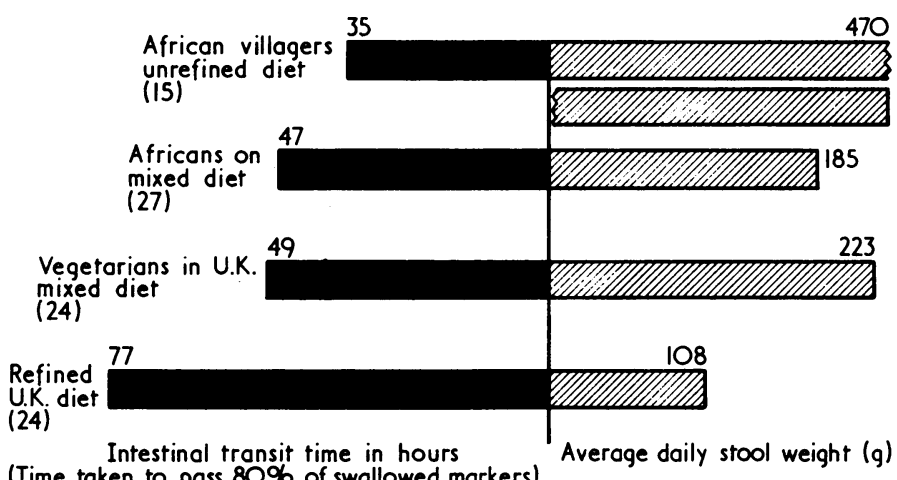

(Time taken to pass $80 \%$ of swallowed markers)

Intestinal transit times and average daily weight of stools in groups of volunteers on high-residue, mixed, and low-residue diets. (Numbers in parentheses indicate number of volunteers in trial.)

The only previous hypothesis for the causation of varicose veins, deep vein thrombosis, and haemorrhoids consistent with the epidemiological evidence and fulfilling the above postulates is that first put forward by Cleave $(1959,1960)$, who believes that the fundamental cause of these conditions is faecal arrest, which results from the fibre-depleted diet characteristic of Western civilization. With this I entirely agree. There seems to be no community living on a high-residue diet in which these venous disorders are other than rare, nor any which has changed from a high-residue to a low-residue diet a generation or more ago and in which these conditions are not all common, all of which supports Cleave's incrimination of fibre deficiency.

It is of interest that the incidence of pulmonary embolism rose 
steeply at about the turn of the century. Wilson (1912) reported that no case of sudden death attributable to pulmonary embolism occurred at the Mayo Clinic between 1889 and 1899. In the next 12 years, with many of the same physicians still on the staff, there were 47 cases of which 41 were confirmed at necropsy. This suggests that the factor responsible for the steep rise in incidence of deep vein thrombosis early in this century began to operate after the introduction of roller mills in the $1880 \mathrm{~s}$, with the consequent consumption of flour low in fibre content.

\section{Postulated Mechanisms}

Both the following postulated mechanisms set out to explain the relation between faecal arrest and varicose veins, deep vein thrombosis, and haemorrhoids. The first considers local pressures exerted by the loaded bowel to be the causative factor and the second incriminates increased intra-abdominal pressures.

\section{(1) CLEAVE'S EXPLANATION}

Cleave, who postulated local pressures as the causative factor, supported this view with the following arguments:

Anatomical.-The close relation between the iliac colon and the left external iliac vein and similar but less close relation between the caecum and the right external iliac vein (Last, 1966). He argued that the loaded colon can exert minimal but significant pressures on these veins. Similarly he argued that the loaded rectum exerts pressure on the haemorrhoidal veins.

Clinical Evidence.- $\mathrm{He}$ argued that the clinical left-sided preponderance of varicose veins and to a greater extent that of deep vein thrombosis (Negus, 1970) could be explained by the closer anatomical relation on the left resulting in greater pressures on this side, this being more marked when supine than erect. He refused an explanation based on the crossing of the right common iliac artery over the left common iliac vein (Cockett et al., 1967) because of the conflict with the evolutionary principles and the absence of this condition in tribal Africans.

Change in Hospital Routine.-He claimed that the rapid rise in the incidence of deep vein thrombosis in the last 20 years (Morrell et al. 1963) could be related to the abandonment of the routine hospital practice of endeavouring to empty the colon by purgatives and enemata. He postulated that his explanation, if proved correct, could be of fundamental importance in prophylaxis (Cleave, 1972).

\section{(2) SUGGESTED ALTERNATIVE EXPLANATION}

There is abundant evidence that a low-residue diet is responsible for the raised pressures within the lumen of the colon which result in diverticular disease (Painter, 1969, 1970; Painter and Burkitt, 1971).

Constipation not only causes raised intraluminal pressures but also necessitates straining at stool. In many people this can raise intra-abdominal pressures to as much as $200 \mathrm{mg} \mathrm{Hg}$ (Dodd, 1964 ; D. Edwards, personal communication, 1971). Painter et al. (1972) showed that restoring indig :stible fibre to the diet greatly reduces the need to strain at stool. The impulse on coughing, which indicates incompetence of saphenous valves, demonstrates the ease with which raised intra-abdominal pressures can be transmitted to the veins of the lower limb. The valves when competent must sustain these transmitted pressures, but repeated and prolonged episodes of straining and the effect of gravity resultant on valve incompetence could lead to changes in both the superficial and the deep veins of the lower limbs.

The rise in incidence of both varicose veins and deep vein thrombosis with age (Coon and Coller, 1959; Sevitt and Gallagher, 1961) suggests a progressive pathological process, and the association between deep vein thrombosis and varicose veins suggests a common or related cause (Kakkar et al., 1970).
The traditional squatting position adopted for defaecation may protect the veins of the lower limb from intra-abdominal pressures (A. A. Osman, personal communication, 1971).

It is postulated that the increased venous pressures due to straining at stool could cause dilatation or other change in both the superficial and the deep venous system of the leg-in the deep venous system resulting in some venous stasis during enforced recumbency. This explanation could, in communities on a low-residue diet, account for venous thrombosis being virtually limited to the legs and affecting both equally. An additional factor must be responsible for the tendency for thrombi in the left leg to become clinically manifest more often than those in the right leg. Cockett et al. (1967) incriminated the compression of the left common iliac vein by the right common iliac artery, whereas Cleave (1960) blamed pressure of a loaded iliac colon on the left external iliac vein.

Abdominal straining, possibly in combination with direct pressure on haemorrhoidal veins, could likewise account for the development of haemorrhoids. Thrombosis in haemorrhoids could be accounted for by temporary high intravenous pressure stretching and rupturing the endothelial lining, the resultant uncovered area initiating the thrombosis $(H$. Dodd, personal communication, 1971). The observation that haemorrhoids appear before varicose veins in developing countries could be explained by the fact that the haemorrhoidal veins, having no valves, are unprotected from intra-abdominal pressures, whereas the leg veins would initially be protected by the valves.

\section{Conclusions}

(1) Varicose veins and deep vein thrombosis are closely associated epidemiologically with one another and with diverticular disease. Haemorrhoids are similarly associated but to a lesser degree.

(2) Not only are varicose veins and diverticulosis closely associated epidemiologically but $\mathrm{C}$. Latto and $\mathrm{R}$. Wilkinson (personal communication, 1971) showed that they tend to be associated in individuals. This further suggests a common causative factor.

(3) There can be little doubt that diverticular disease is due to increased intraluminal pressures resulting from the faecal arrest caused by a low-residue diet.

(4) A low-residue diet not only causes raised intraluminal pressures in the colon but also increased intra-abdominal pressures during straining at stool.

(5) Communities who strain at stool have a high incidence of varicose veins and vice versa.

(6) When the valves of the lower limb veins are incompetent abdominal pressures are readily transmitted to the veins. It may therefore be assumed that these pressures are applied to the valves when competent.

(7) Abdominal pressures are also transmitted to haemorrhoidal veins.

(8) Unformed stools are characteristic of communities with a low incidence of varicose veins and vice versa.

(9) Communities who squat at stool seem to have a low incidence of varicose veins.

(10) When traditional diet in a community gives way to more refined foods the incidence of haemorrhoids always rises before that of varicose veins.

(11) Varicose veins, diverticular disease, cancer of the colon, and constipation are all more prevalent in women.

All available evidence is thus consistent with the hypothesis that varicose veins, deep vein thrombosis, and haemorrhoids are the result of the faecal arrest associated with a low-residue diet. I am aware of no other hypothesis consistent with the epidemiological facts.

I wish to express my gratitude to Captain T. L. Cleave, who first drew my attention to the relation between these venous disorders and a low-residue diet. My thanks are due to the Medical 
Assistance Programmes Incorporated of Illinois for helping me to collect information from mission hospital. Finally, I am gratefu to my personal assistant, Miss Ella Wright, for her unstinted conscientious help. The illustration was prepared by Miss Sandra Osborn.

\section{References}

Allen, E. V., Barker, N. W., and Hines, E. A. (1962). Peripheral Vascular Diseases, p. 636. Philadelphia, Saunders.

Atkins, H. G. B. (1938). Guv's Hospital Reports, 18, 92.

Bailey and Love's Short Practice of Surgery (1968). Ed. A. J. H. Raines and W. M. Capper, 14th edn., pp. 144, 989. London, Lewis.

Barker, A. (1964). Lancet, 2, 970.

Barker, J. T. (1941). Proceedings of the Staff Meetings of the Mayo Clinic, 16,

Barlow, M. B., Ginsberg, H., and Gottlich, J. (1953). South African Medical fournal, 27, 242 .

Browse, N. L., and Negus, D. (1970). British Medical fournal, 3, 615.

Burkitt, D. P. (1969). Lancet, 2, 1229.

Burkitt, D. P. (1970). Lancet, 2, 1237.

Burkitt, D. P. (1971). Cancer, 28, 3.

Burkitt, D. P., Walker, A. R. P., and Painter, N. S. (1972). In preparation.

Calnan, J. S., Pflug, J. J., and Mills, C. J. (1970). Lancet, 2, 502.

Campbell, G. C., and Cleave, T. L. (1968). British Medical fournal, 3, 741.

Chakrabarti, R., et al. (1968). Lancet, 1, 987.

Clarke, C., and Cotton, L. T. (1968). British fournal of Surgery, 55, 211.

Cleave, T. L. (1959). Lancet, $2,172$.

Cleave, T. L. (1960). On the Causation of Varicose Veins. Bristol, Wright.

Cleave, T. L. (1972). British Medical fournal, 1, 629.

Cleave, T. L., Campbell, G. C., and Painter, N. S. (1969). Diabetes, Coronary Thrombosis and the Saccharine Disease, 2nd edn. Bristol, Wright.

Cockett, F. B., Lea Thomas, M., and Negus, D. (1967). British Medical Fournal, 2, 14

Coon, W. W., and Coller, F. A. (1959). Surgery, Gynecology and Obstetrics with International Abstracts of Surgery, 109, 487.

Davies, J. N. P. (1948). East African Medical fournal, 25, 322.

Davis, L. (editor) (1968). Christopher's Textbook of Surgery, 9th edn., pp. 729, 1298. Philadelphia, Saunders.

de Takatas, C., and Quint, M. (1930). Surgery, Gynecology and Obstetrics with International Abstracts of Surgery, $50,545$.

Dodd, H. (1964). Lancet, 2, 809.

Dodd, H., and Cockett, F. B. (1956). The Pathology and Surgery of the Veins of the Lower Limb, p. 3. Edinburgh, Livingstone.

Doran, F. S. A. (1971). British Fournal of Hostital Medicine, 6, 773.

Doran, F. S. A., Drury, M., and Sivyer, A. (1964). British fournal of Surgery,

51, 486.
Doran, F. S. A., White, M., and Drury, M. (1970). British fournal of Surgery, 57,20

Flanc, C., Kakkar, V. V., and Clarke, M. B. (1969). Lancet, 1, 477.

Gabriel, W. B. (1963). Rectal Surgery, 5th edn., p. 111. London, Lewis.

General Register Office (1969). Statistical Review of England and Wales: Part I, Tables Medical. London, H.M.S.O.
Gibbs, N. (1959). British fournal of Surgery, 47, 282.

Grundy, F., and Lewis-Faning, E. (1957). Morbidity and Mortality in the First Year of Life. London, Eugenics Society.

Kakkar, V. V., Howe, C. T., Nicolaides, A. N., Renney, J. T. G., and Clarke, M. B. (1970). American fournal of Surgery, 120, 527 .

Kemble, J. V. H. (1971). British fournal of Hospital Medicine, 6, 71.

Lambie, J. M., et al. (1970). British Medical fournal, 2, 142.

Lambie, J. M., et al.

Last, R. J. (1966). Anatomy, Regional and Applied. London, Churchill.

Little, J. M., Loewenthal, J., and Mills, F. H. (1966). British fournal of Surgery, 53, 657.

Luyombya-Sengero, J. M. (1968). Makerere Medical fournal, 12, 20.

Martin, P., Lynn, P. B., Dible, J. H., and Aird, J. (1956). Peripheral Vascular Disorders, p. 669. Edinburgh, Livingstone.

Mavor, G. E. (1969). British Medical fournal, 4, 680.

Mekky, S., Schilling, R. S. F., and Walford, J. (1969). British Medical Fournal, 2, 591

Ministry of Pensions and National Insurance (1962). Report, 1961. Cmnd. 1764. London, H.M.S.O.

Morrell, M. T., Truelove, S., and Barr, A. (1963). British Medical fournal, 2,830 .

Negus, D. (1970). Annals of the Royal College of Surgeons of England, 47, 92

Negus, D., Pinto, D. J., Le Quesne, L. P., and Brown, N. (1969). Acta Chirurgica Belgica, 68, 507.

Nicolaides, A. N., et al. (1971). British Medical fournal, 1, 432.

Painter, N. S. (1969). Lancet, 2, 586.

Painter, N. S. (1970). Proceedings of the Royal Society of Medicine, 63, Suppl., p. 144. painter, N. S., Almeida, A. Z., and Colebourne, K. W. (1972). British
Medical fournal, 2, 137.

Painter, N. S., and Burkitt, D. P. (1971). British Medical Journal, 2, 450.

Richards, R. L. (1966). British Medical fournal, 2, 217.

Roberts, V. C. (1971). New Scientist, 51, 620.

Roberts, V. C., Sabri, S., Pietroni, M. C., Gurewich, V., and Cotton, L. T. (1971). British Medical fournal, 3, 78 .

Sabri, S., Roberts, V. C., and Cotton, L. T. (1971). British Medical fournal, 3,82

Sevitt, S., and Gallagher, N. G. (1959). L.ancet, 2, 981

Sevitt, S., and Gallagher, N. (1961). British fournal of Surgery, 48, 475.

Shaper, A. G. (1970). Atherosclerosis: Proceedings of the 2nd International Symposium, ed. R. J. Jones, p. 314. Heidelberg, Springer.

Shaper, A. G., Jones, K. W., Kyobe, J., and Jones, M. (1966). fournal of Atherosclerosis Research, 6, 313.

Sripad, S., Antcliff, A. C., and Martin, P. (1971). British fournal of Surgery, $58,563$.

Stamler, J. (1958). Fournal of the National Medical Association, 50, 161.

Stelzner, F. (1963). German Medical Monthly, 8, 177.

Thomas, W. A., Davies, J., O'Neal, R. M., and Dimakulangan, A. A. (1960), American fournal of Cardiology, 5, 41 .

Trowell, H. C. (1960). Non-infective Disease in Africa, p. 218. London, Arnold.

Virchow, R. L. K. (1856). In Gesammelte abhandlungen zur wissenschaftlichen Medicin, p. 219. Frankfurt, Meidinger.

Walker, A. R. P. (1961). South African Medical fournal, 35, 114

Walker, A. R. P. (1971). South African Medical fournal, 45, 377.

Wilson, C. B. (1912). Annals of Surgery, 56, 809 .

Wright, H. P., Osborn, S. B., and Edmonds, D. G. (1951). Lancet, 1, 22.
Department of Medicine, University Hospital, Zurich, Switzerland PETER J. GROB, M.D., Section of Clinical Immunology GIAN E. HEROLD, M.D., Resident

\section{Introduction}

Hydantoins and their derivatives are a mainstay of antiepileptic and lately of antiarrhythmic therapy. In the course of the long history of their therapeutic use a broad spectrum of side effects has been attributed to these drugs (Sparberg, 1963), most frequently consisting of visual disturbances, gingival hyperplasia (King, 1952; Sparberg, 1963; Goodman and Gilman, 1970), and various exanthemas (Mandelbaum and Kane, 1941; Loscalzo, 1948; Martin et al., 1954; Watts, 1962). Other side effects described have been haematological abnormalities (Benhamon and Albon, 1953; Best and Paul, 1950; Sparberg, 1963), benign (Siegal and Berkovitz, 1961; Harrington et al., 1962; Holland and Mauer, 1965; Goodman and Gilman, 1970) and, rarely, malignant lymphadenopathies (Hyman and Sommers, 1966), hepatitis (Chaiken et al., 1950; Gropper, 1956; Bajoghli, 1961; Pezzimenti and Andrew, 1970), disease states resembling serum sickness (Bravermann and Levin, 1963), lupus erythematosus (Miescher and Delacrétaz, 1953; Lindquist, 1957; Rallison et al., 1961) and periarteritis nodosa (Van Wyk and Hoffman, 1948), and endocrine disorders such as hirsutism (Sparberg, 1963; Kniper, 1969). 